University of Nebraska - Lincoln

DigitalCommons@University of Nebraska - Lincoln

USDA National Wildlife Research Center - Staff Publications
U.S. Department of Agriculture: Animal and Plant Health Inspection Service

January 1978

\title{
MOVEMENT AND MIGRATION PATTERNS OF RED-WINGED BLACKBIRDS: A CONTINENTAL OVERVIEW
}

Richard A. Dolbeer

Follow this and additional works at: https://digitalcommons.unl.edu/icwdm_usdanwrc

Part of the Environmental Sciences Commons

Dolbeer, Richard A., "MOVEMENT AND MIGRATION PATTERNS OF RED-WINGED BLACKBIRDS: A CONTINENTAL OVERVIEW" (1978). USDA National Wildlife Research Center - Staff Publications. 152. https://digitalcommons.unl.edu/icwdm_usdanwrc/152

This Article is brought to you for free and open access by the U.S. Department of Agriculture: Animal and Plant Health Inspection Service at DigitalCommons@University of Nebraska - Lincoln. It has been accepted for inclusion in USDA National Wildlife Research Center - Staff Publications by an authorized administrator of DigitalCommons@University of Nebraska - Lincoln. 


\title{
MOVEMENT AND MIGRATION PATTERNS OF RED-WINGED BLACKBIRDS: A CONTINENTAL OVERVIEW
}

\author{
By Richard A. Dolbeer \\ INTRODUCTION
}

From 1924 through 1974, about 11,000 recoveries accumulated from the banding of over 700,000 Red-winged Blackbirds (Agelaius phoeniceus) in North America. A few studies have examined some of these data for specific localities during certain times of the year; however, no attempt has been made to examine the total recovery data to compile a general picture of continental movement and migration patterns.

Increasing attention is being given to blackbird (Icteridae) and Starling (Sturnus vulgaris) populations in North America because of their reported crop depredations, health hazards, and nuisance aspects, especially when congregating in large roosts (Meanley, 1975; Graham, 1976). Solutions to these problems are difficult to find because the problems are widespread and the populations are highly mobile. Management measures necessary in one area may have effects in areas far removed. Thus, effective management requires a thorough knowledge of the overall movement and migration pattern of each species.

The objectives of this study are to: (1) determine the general continental movement and migration patterns of the Red-wing during the annual cycle, and (2) examine banding and recovery numbers in relation to population numbers on a regional basis to pinpoint areas where additional banding and/or recovery effort is needed.

\section{METHODS}

The range of the Red-wing in North America was partitioned into 27 regions (Fig. 1), which served as the basic geographical units of the analyses. In eastern North America, the regions were based primarily on ecological zones (e.g., Appalachian Region, Florida Peninsula, Lower Mississippi Valley). In western North America, because of the lower banding rate and sparser Red-wing populations, regions generally encompassed larger areas and were not closely aligned along ecological boundaries.

The annual cycle of the Red-wing was divided into five seasonal periods: (1) reproductive (25 April-31 July), (2) postreproductive (1 August-15 October), (3) fall migration (16 October-9 December), (4) winter roost (10 December-20 February), and (5) spring migration-prereproductive (21 February-24 April). The dates of the reproductive period were based upon data obtained from a literature review on nesting chronology for Red-wings in North America (Dolbeer, 1976; Dolbeer et al., 1976); these dates encompass the nesting and immediate postfledging period for most Red-wings in North America. The dates for the other periods were based on analysis of distances moved by birds banded during the reproductive period and recovered during semi- 


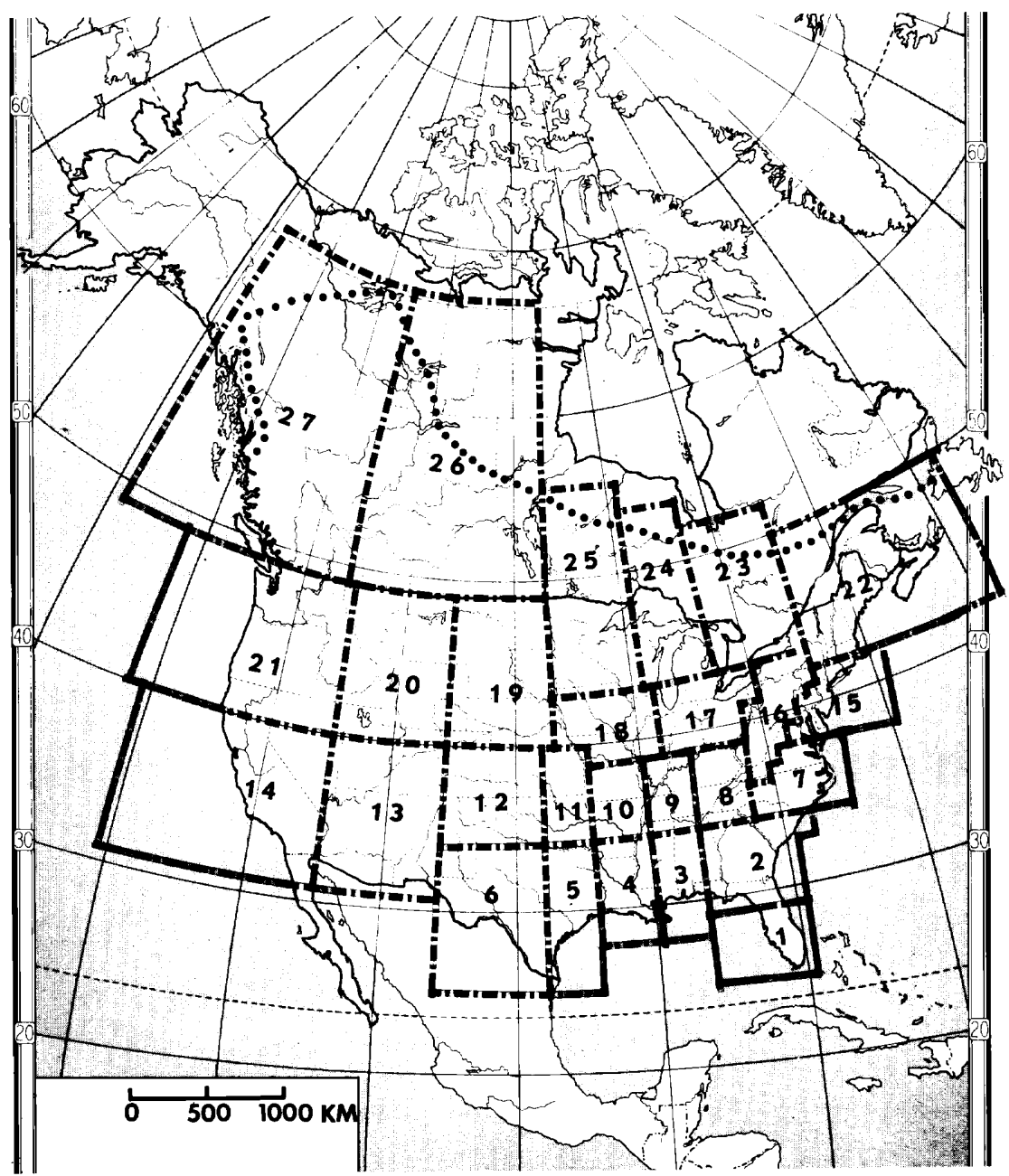

FIGURE 1. The 27 regions used in the analysis of Red-winged Blackbird band-recovery data. The dotted line represents the approximate northern boundary of the range of the Red-wing.

monthly periods (see Results). Although the periods are not precise for Red-wings in all regions (particularly $26-27$ ), they provide fairly accurate time units for the overall continental analyses presented here.

For a recovery record to be included in the analysis, it had to provide the complete date of banding and recovery and the latitudinal and longitudinal coordinates (to the nearest degree) for banding and recovery. Of the 11,000 records, about 2,000 were excluded because of incomplete information.

Recoveries obtained at banding stations were omitted from the anal- 
yses in which: (1) distances between banding and recovery locations were calculated for various time periods, or (2) the distribution of recoveries was calculated for birds banded in a certain region. Both of these analyses require that recoveries be random events and because banding stations are located nonrandomly in North America, the use of banding station recoveries would have biased the analyses.

Banding and recovery effort by region was calculated for the reproductive-postreproductive period (25 April-15 October) and for the winter-roost period (10 December-20 February). Banding effort by region for a seasonal period was the number of birds banded in that region and subsequently recovered, divided by an index of the average population number for the region during that seasonal period. I used only banded birds that had been recovered (instead of total banded birds) because I was measuring productive banding effort and not banding effort per se. Recovery efforts were similarly calculated using the number of recoveries in a given region.

The indices of population density during the reproductive-postreproductive period were the average number of Red-wings recorded per Breeding Bird Survey (see Robbins and Van Velzen, 1969, for description) route run in each region from 1966-74. The density index was then multiplied by the estimated land area for the region to obtain an index of population numbers. The indices of population numbers during the winter-roost period were obtained by totaling the number of roosting Red-wings recorded in each region during the 1974-75 nationwide winter-roost survey (Meanley, B. 1976. Unpubl. Prog. Rep., Work Units P-F-25.1, 25.2. Patuxent Wildl. Res. Center, Laurel, Maryland. 82 p.).

\section{RESULTS}

\section{Distances Between Banding and Recovery Sites}

Reproductive period.-Average distances between banding and recovery sites for Red-wings banded and recovered in the same reproductive period were less than $25 \mathrm{~km}$ in all regions, indicating limited movement during the reproductive period (Table 1). Of the 150 recoveries, 97 percent were $<100 \mathrm{~km}$ from the banding sites.

Average distances between banding and recovery sites, when banding and recovery were in different years, were generally $<50 \mathrm{~km}$, indicating that Red-wings normally return to breed at or near their hatching or nesting site (Table 1). Of the 349 recoveries, 91 percent were $<100 \mathrm{~km}$ from the banding site. Exceptions occurred in the central plains and Rocky Mountain regions (19-20) where the average distance for 14 recoveries was $148 \mathrm{~km}$. This high value is partially explained by one recovery of a nestling-banded bird $>1,000 \mathrm{~km}$ from the banding site. In general, birds banded during their hatching year were recovered at greater distances than were birds banded during their second or later years. Nero (1956:6-7) and Laux (1970) also reported the tendency of Red-wings to return annually to the same locality to breed. 
TABLE 1

Average distance $(\mathrm{km})$ between banding and recovery site for Red-winged Blackbirds banded and recovered during the reproductive period, 25 April-31 July. All recoveries obtained at banding stations are excluded. Number of recoveries are in parentheses.

\begin{tabular}{|c|c|c|c|c|c|c|}
\hline \multirow[b]{3}{*}{ Regions } & \multirow{2}{*}{\multicolumn{2}{|c|}{$\begin{array}{c}\text { Banding and recovery } \\
\text { in same calendar } \\
\text { year }\end{array}$}} & \multicolumn{4}{|c|}{ Banding and recovery in different calendar year } \\
\hline & & & \multicolumn{2}{|c|}{$\begin{array}{c}\text { Banded as hatching- } \\
\text { year bird }\end{array}$} & \multicolumn{2}{|c|}{$\begin{array}{l}\text { Banded as after- } \\
\text { hatching-year bird }\end{array}$} \\
\hline & $\begin{array}{l}\text { Av. } \\
\text { distance }\end{array}$ & $\begin{array}{l}\text { No. } \\
<100 \mathrm{~km}\end{array}$ & $\begin{array}{c}\text { Av. } \\
\text { distance }\end{array}$ & $\begin{array}{c}\text { No. } \\
<100 \mathrm{~km}\end{array}$ & $\begin{array}{c}\text { Av. } \\
\text { distance }\end{array}$ & $\begin{array}{l}\mathrm{No} \\
<100 \mathrm{~km}\end{array}$ \\
\hline $1-6$ & $3.3(13)$ & 13 & $4.6(4)$ & 4 & $7.0(7)$ & 7 \\
\hline $7-12$ & $5.7(7)$ & 7 & $21.9(14)$ & 13 & $5.5(22)$ & 22 \\
\hline $13,14,21$ & $12.6(4)$ & 4 & $15.5(3)$ & 3 & $9.2(3)$ & 3 \\
\hline 15,16 & $17.2(25)$ & 24 & $17.3(29)$ & 27 & $16.1(56)$ & 52 \\
\hline 17,18 & $6.8(42)$ & 42 & $45.4(41)$ & 34 & $27.0(47)$ & 41 \\
\hline 19,20 & $9.6(4)$ & 4 & $210.7(4)$ & 2 & $122.4(10)$ & 7 \\
\hline $22-25$ & $24.5(51)$ & 47 & $47.3(27)$ & 24 & $27.9(78)$ & 72 \\
\hline 26,27 & $5.2(4)$ & 4 & $20.3(4)$ & 4 & $-\quad(0)$ & - \\
\hline
\end{tabular}

Reproductive period to subsequent semi-monthly periods.-The average distance between banding and recovery sites for birds banded during the reproductive period and recovered during subsequent semi-monthly periods (e.g., 1-15 August, 16-31 August) was calculated by region. The same calculations also were made for birds recovered during the reproductive period that had been banded during these semi-monthly periods, and the two data sets combined. These analyses were made to determine the times of year Red-wings undertake major movements away from or toward their breeding locations.

For most regions, movements during the postreproductive period were $<200 \mathrm{~km}$ from the birds' localities during the reproductive period (Table 2, Fig. 2). Previous studies in the Chesapeake Bay area (Meanley, 1964; Meanley and Bond, 1970), New York State (Allen, 1914), and the mid-southern United States (Meanley, 1971: 14) also have indicated that Red-wings normally remain close to their breeding areas until after the fall molt is completed in early October. However, apparently not all populations are sedentary at this time. The results from the northwestern regions (26-27), where the average distance moved was $729 \mathrm{~km}$, show that many Red-wings undertake rather extensive southerly migrations during August and September before the fall molt is complete. These results are consistent with the report by Smith and Bird (1969) that southward migration begins in mid-August for Red-wings breeding in Manitoba. Packard (1936) also found that some Red-wings breeding in the coastal areas of Massachusetts move as far south as southern New Jersey during August and September.

Fall migration to winter-roost areas generally occurred during November for populations indigenous (present during the reproductive 
TABle 2

Average distance $(\mathrm{km})$ between banding and recovery site for Red-winged Blackbirds banded 25 April-31 July and recovered 1 August-15 October or vice versa. Birds are assigned to the region in which they were banded or recovered during the period 25 April-31 July. All recoveries obtained at banding stations are excluded. Sample size is in parentheses.

\begin{tabular}{cc}
\hline \hline Regions & Distance $(\mathrm{km})$ \\
\hline $1-6$ & $61.6(21)$ \\
$7-9$ & $193.0(15)$ \\
$10-12$ & $59.2(14)$ \\
$13,14,21$ & $23.6(13)$ \\
15,16 & $134.6(77)$ \\
17,18 & $64.2(114)$ \\
19,20 & $110.6(35)$ \\
$22-25$ & $85.7(40)$ \\
26,27 & $729.4(11)$ \\
\hline
\end{tabular}

period) to the northern regions (15-25) as shown for regions 15-16, 17-18, and 22-25, where sample size was largest (Fig. 2). Movements during the winter-roost period were apparently most limited during the months of December through early February. Spring migration began in late February through March except in the central plains and Rocky Mountain regions (19-20) where birds were still commonly found $>500$ $\mathrm{km}$ from their breeding localities as late as March and early April (Fig. 2 ) and in the northwest regions (26-27) where the five birds recovered from 1 March-15 April averaged 1,490 km from their breeding localities.

Winter-roost period.-Average distances between banding and recovery sites for Red-wings banded and recovered in the same winter-roost period were $<25 \mathrm{~km}$, except in regions $10-12$ where 13 recoveries averaged $64 \mathrm{~km}$ from banding sites (Table 3 ). For all regions combined, only 4 of 69 recoveries $(6 \%)$ were $>100 \mathrm{~km}$ from banding sites showing that Red-wings are rather sedentary during a single winter-roost period.

The average distance between banding and recovery sites for Redwings recovered at least one winter after banding were similar to the same winter-recovery distances in regions 1 and 19-20 but were substantially longer $(154-231 \mathrm{~km})$ for the other regions (Table 3, Fig. 3). For example, red-wings roosting in eastern Texas, Arkansas, and Oklahoma apparently commonly shift their roosting sites between years among these three states. For all regions combined, 19 of 92 recoveries $(21 \%)$ were $>100 \mathrm{~km}$ from the banding sites. Thus, there appears to be less faithfulness to the same annual winter roosting site (Table 3, Fig. 3) than there is for the same annual breeding site (Table 1). A similar shifting of birds from one winter to the next was found for Common Grackles (Quiscalus quiscula) in Texas (Royall 1973). 

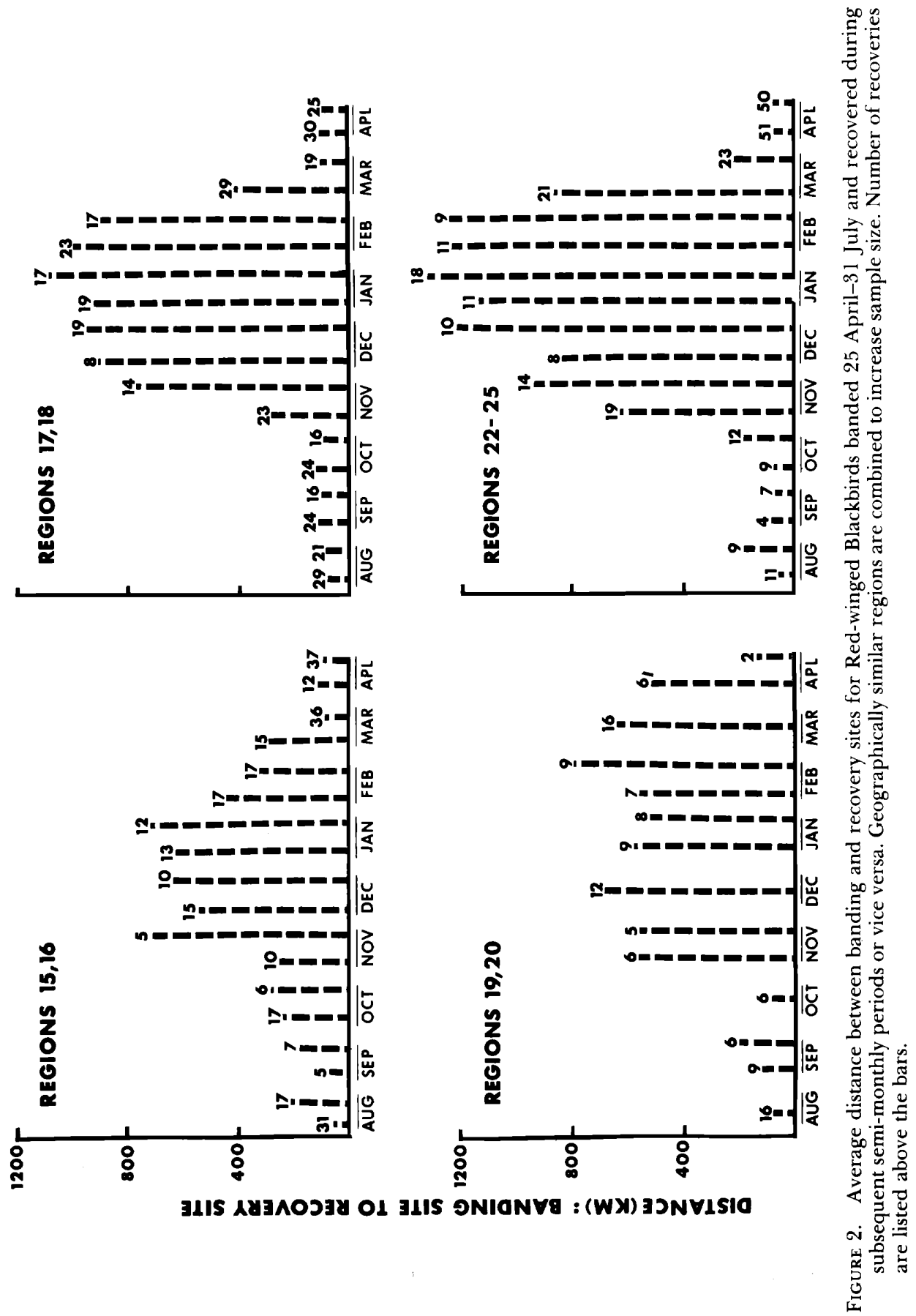
TABLE 3

Average distance $(\mathrm{km})$ between banding and recovery site for Red-winged Blackbirds banded and recovered during the winter-roost period, 10 December-20 February. All recoveries obtained at banding stations are excluded. Number of recoveries are in parentheses.

\begin{tabular}{|c|c|c|c|c|}
\hline \multirow[b]{2}{*}{ Regions $^{1}$} & \multicolumn{2}{|c|}{$\begin{array}{l}\text { Banding and recovery in } \\
\text { same winter }\end{array}$} & \multicolumn{2}{|c|}{$\begin{array}{l}\text { Banding and recovery in } \\
\text { different winters }\end{array}$} \\
\hline & Av. distance & $\begin{array}{l}\text { No. } \\
<100 \mathrm{~km}\end{array}$ & Av. distance & $\begin{array}{l}\text { No. } \\
<100 \mathrm{~km}\end{array}$ \\
\hline 1 & $12.0(16)$ & 15 & $11.7(31)$ & 31 \\
\hline $2-5$ & $20.3(20)$ & 19 & $153.5(31)$ & 21 \\
\hline $7-9$ & $-(0)$ & - & $18.5(1)$ & 1 \\
\hline $10-12$ & $64.5(13)$ & 11 & $230.9(13)$ & 6 \\
\hline 15 & $6.8(9)$ & 9 & $226.6(4)$ & 2 \\
\hline 19,20 & $16.1(11)$ & 11 & $22.9(12)$ & 12 \\
\hline
\end{tabular}

${ }^{1}$ No data for regions $6,13,14,16-18$, and $21-27$.

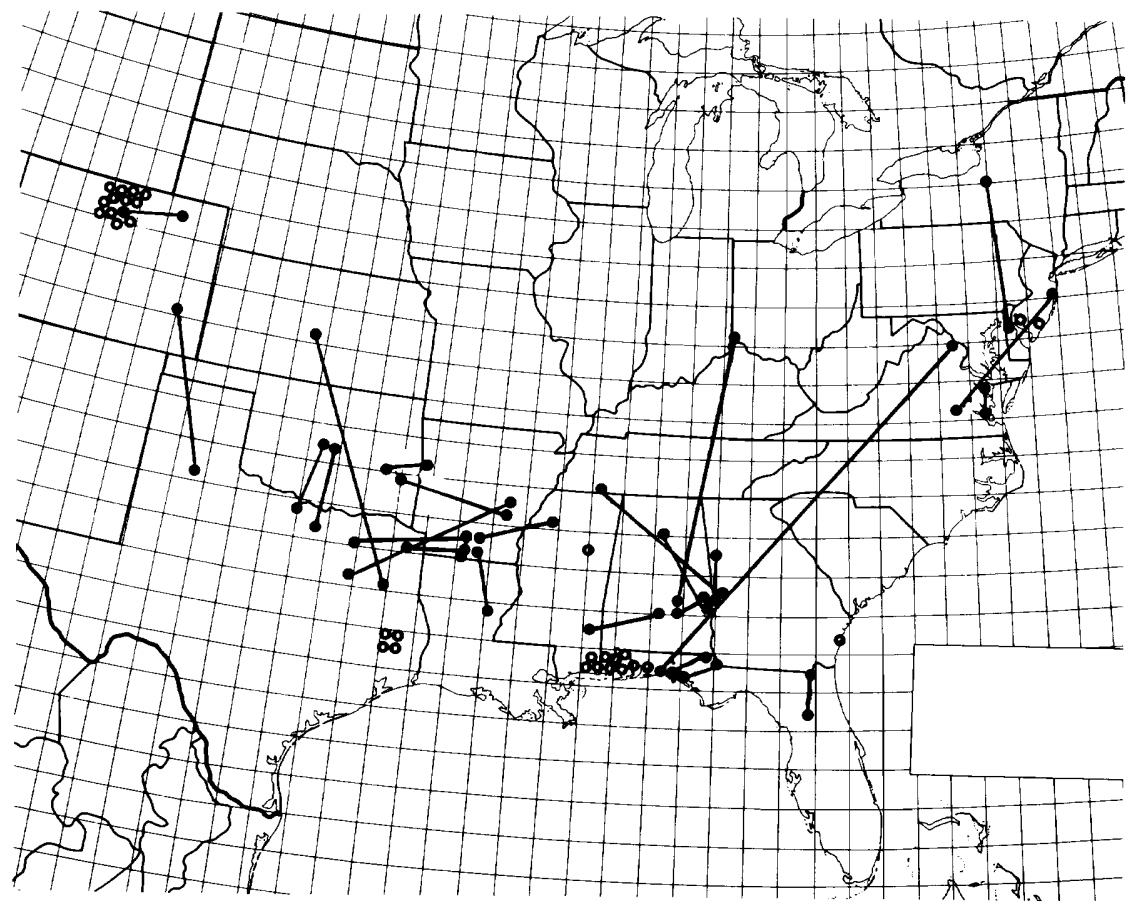

FIGURE 3. Banding and recovery sites for Red-winged Blackbirds banded and recovered in winter-roost periods (10 December-20 February) during different years. Lines connect banding and recovery sites for one bird when these sites are $>50 \mathrm{~km}$ apart. Open circles represent banding and recovery sites for one bird when these sites are $<50 \mathrm{~km}$ apart. 


\section{Winter Distribution in Relation to Location During the Reproductive Period}

To estimate where the birds present in each region during the reproductive period go during the winter-roost period, the following approach was taken. All records of birds banded during the combined (to increase sample size) reproductive-postreproductive period and recovered during the winter-roost period were assembled by region. The percentage of recoveries occurring in each region then was calculated to provide a tabular display of the general winter-distributional pattern for the populations indigenous to each region (Table 4).

The distribution of recoveries is best exemplified for birds banded in regions $15,16,17$, and 19 where each recovery-sample size was $>30$. In each of these regions, 33-61\% of the winter recoveries were made in a single region, with the remainder spread among three to seven additional regions. For example, recoveries of birds from the mid-Atlantic coastal region (15), although concentrated in North Carolina, were distributed from south Florida to Massachusetts; recoveries of birds from the lower Great Lakes region (17) ranged from Louisiana to North Carolina; and recoveries of birds from the northern plains States (region 19) were located primarily in east Texas but ranged from eastern Arkansas to northern Colorado (Fig. 4).

The above analysis gives the general winter-distributional pattern for birds indigenous to an entire region. There were two degree blocks in eastern North America (northcentral Ohio-latitude $41^{\circ} \mathrm{N}$, longitude $82^{\circ} \mathrm{W}$; central Chesapeake Bay area-lat. $38^{\circ} \mathrm{N}$, long. $76^{\circ} \mathrm{W}$ ) that have sufficient winter recoveries of reproductive-postreproductive-banded birds available to provide a higher resolution of the winter-distributional pattern for birds indigenous to a local area (Fig. 5). For both degree blocks, winter recoveries were distributed over a wide area with individual recoveries ranging up to $1,125 \mathrm{~km}$ apart. Recoveries of northcentral Ohio birds ranged from the coastal regions of North Carolina to the coastal region of Alabama; Chesapeake Bay birds were recovered from northern Maryland to southern Georgia. These findings are similar to those presented by De Grazio et al. (1969) for winter recoveries of Redwings banded during late summer in Brown County, South Dakota. More limited analyses presented by Meanley (1971: 10-18) and Meanley and Webb (1961) also suggested similar distributional patterns.

\section{Reproductive Period Distribution in Relation to Location During the Winter-Roost Period}

To estimate where the birds banded in each region during the winterroost period go to breed, the converse of the preceding analyses was conducted by reversing the banding and recovery periods (Table 5).

Sample sizes were small for this analysis-only two regions had $>20$ recoveries; thus, the inferences drawn from the distributional data are more limited. For the six regions with 10 or more recoveries (regions $1,2,4,10,12,19$ ), a distributional pattern similar to that for birds 


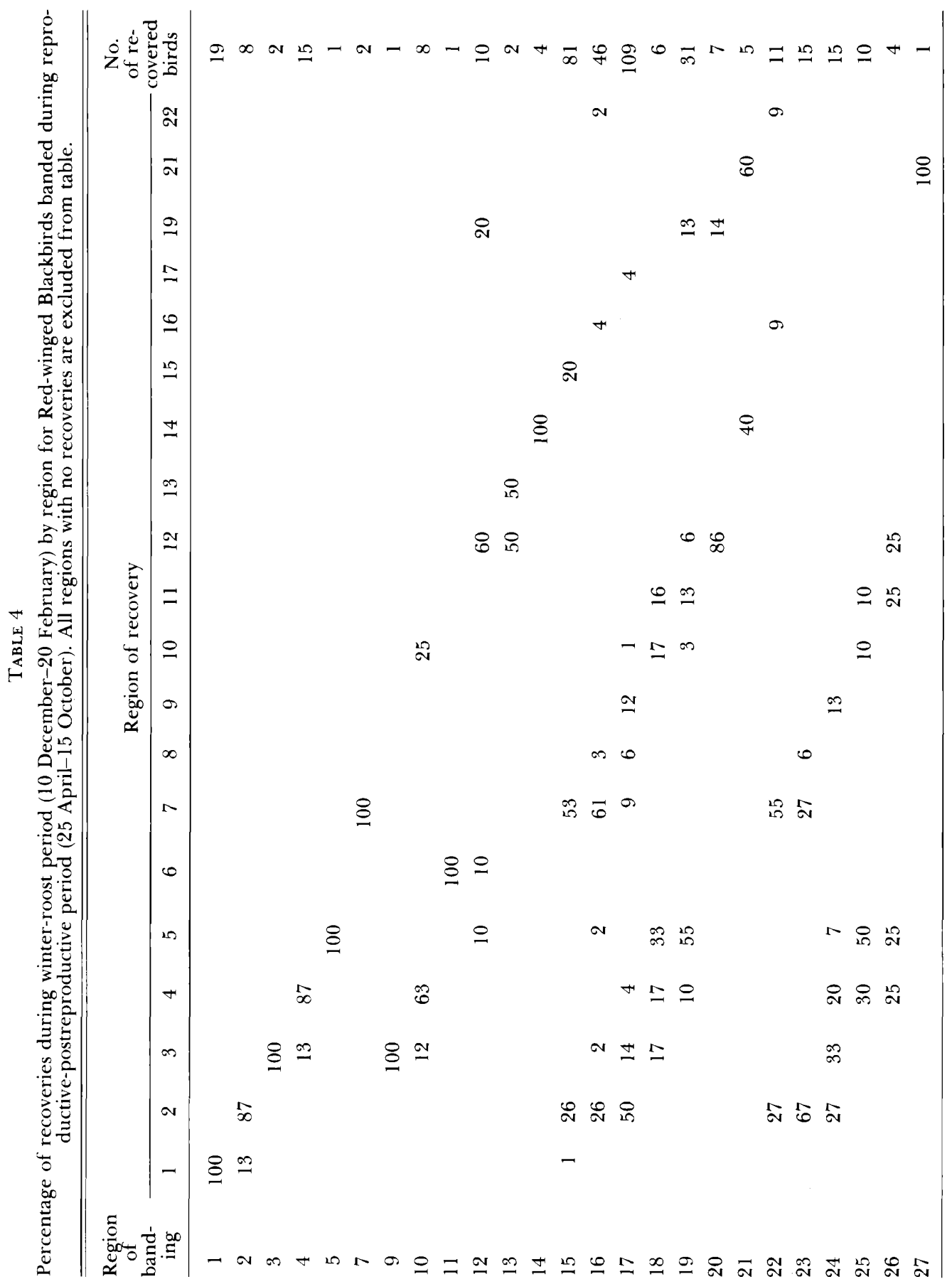




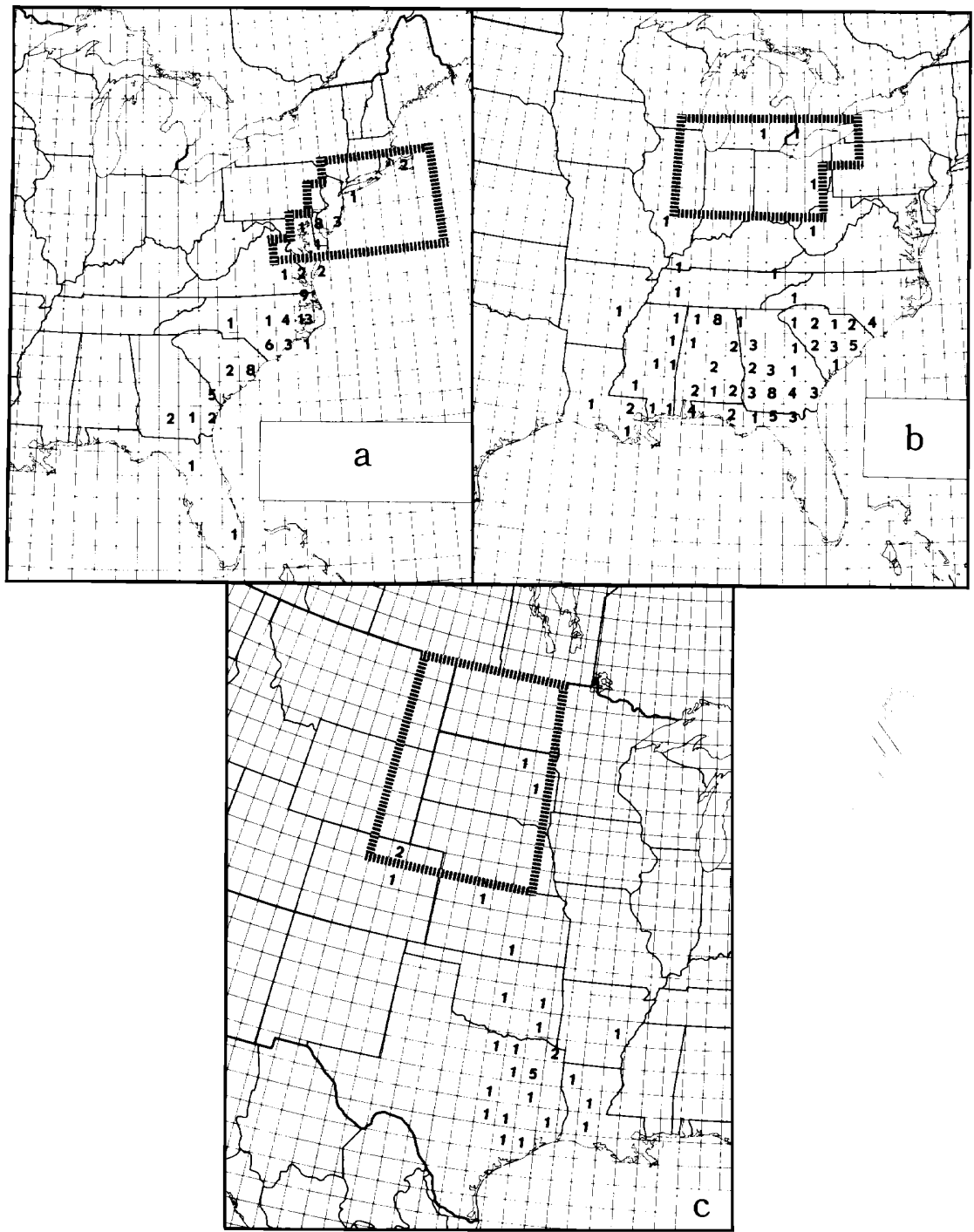

FIGURE 4. Number of recoveries by degree blocks during the winter-roost period (10 December-20 February) for Red-winged Blackbirds banded during the reproductivepostreproductive period (25 April-15 October) in regions 15 (Fig. 4a), 17 (Fig. 4b), and 19 (Fig. 4c).

migrating from breeding areas to wintering areas (Table 4) was evident. For each of these regions, more than $50 \%$ of the recoveries were made in one region and the remaining recoveries were distributed among two to five additional regions (Table 5). For example, birds wintering in region 2 (mostly Georgia and northern Florida) were recovered pri- 


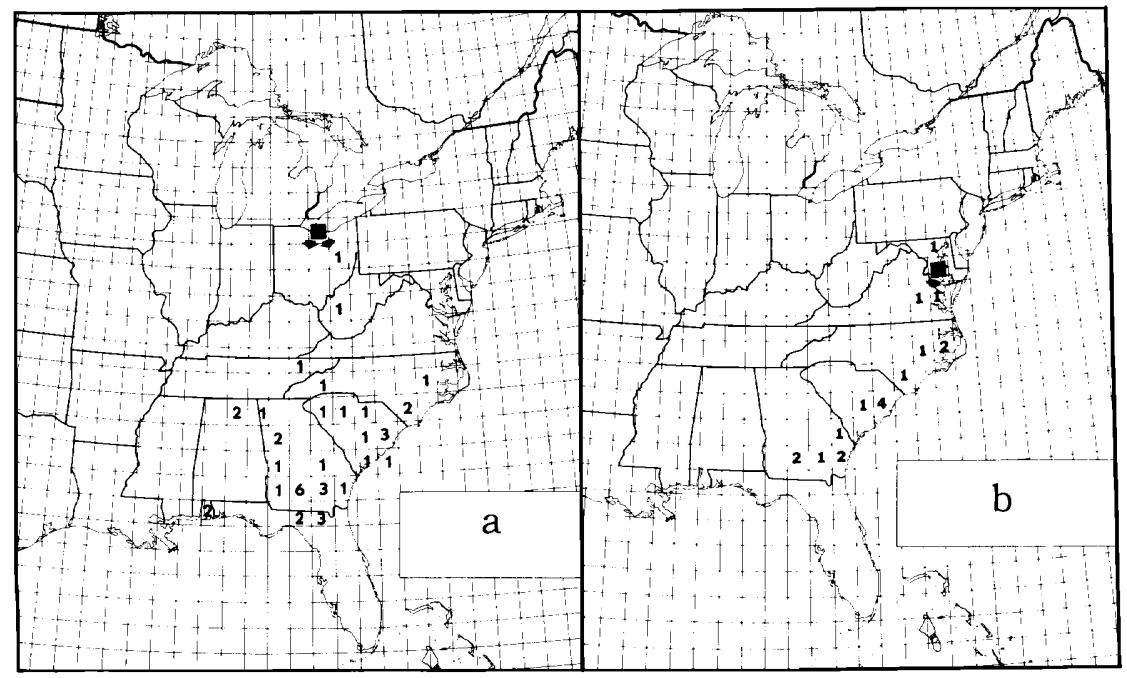

FIGURE 5. Number of recoveries by degree blocks during the winter-roost period (10 December-20 February) for Red-winged Blackbirds banded during the reproductivepostreproductive period (25 April-15 October) in single degree blocks in northern Ohio (Fig. 5a), and in the Chesapeake Bay area (Fig. 5b).

marily in Ohio, southern Michigan, and Georgia; and birds wintering in region 10 (Arkansas, Missouri) were recovered mainly in Minnesota but also in Wisconsin, Arkansas, South Dakota, and Ontario (Fig. 6). The majority of birds banded in winter along the Gulf of Mexico in region 4 were recovered near the Gulf (Fig. 6) suggesting that many of the birds along the Gulf in winter are year-round residents.

\section{Banding and Recovery Effort}

Reproductive-postreproductive period.-Banding effort by region was extremely variable (Table 6), being approximately 2,200 times greater in region 15 (mid-Atlantic coast) than in regions 9 and 6 (western Tennessee-Kentucky and Texas). More than half (15) the regions had $<100$ birds banded during the reproductive-postreproductive period that have been recovered. In all, 6,608 birds banded in the reproductivepostreproductive period have been recovered.

The ranking of regions for recovery effort was similar to that of banding effort (Table 6). Again, more than half the regions had $<100$ birds recovered in them during the reproductive-postreproductive period.

Winter-roost period.-Considerably fewer birds have been banded or recovered during the winter-roost period (Table 7) compared with the reproductive-postreproductive period (Table 6). Region 2 (mostly Georgia-northern Florida) ranks first in both banding effort and recovery effort. Southern regions 3, 5, 7, 9, and 11, all containing large (i.e., over 10 million birds) winter-roosting populations of Red-wings, have very 


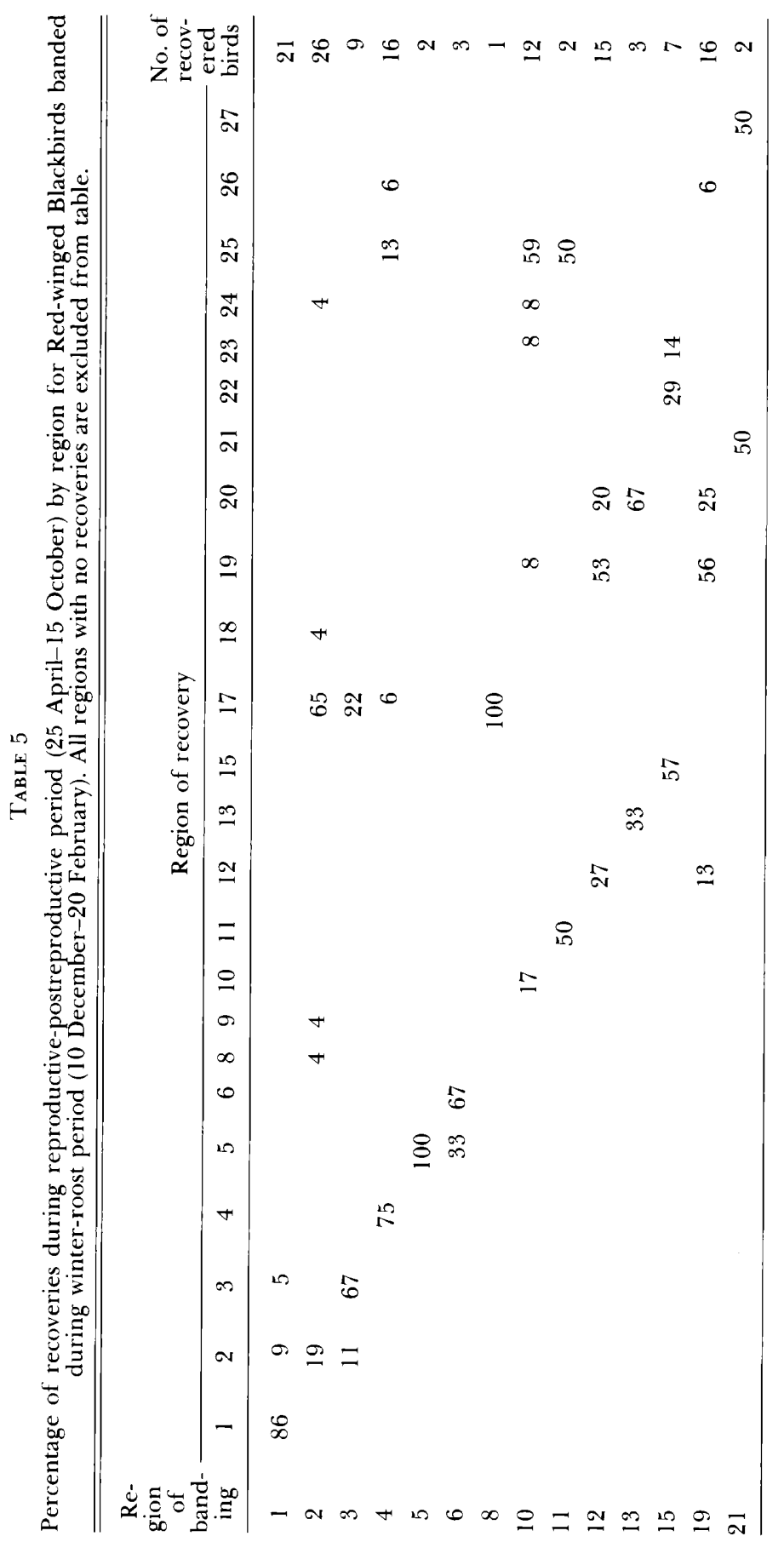




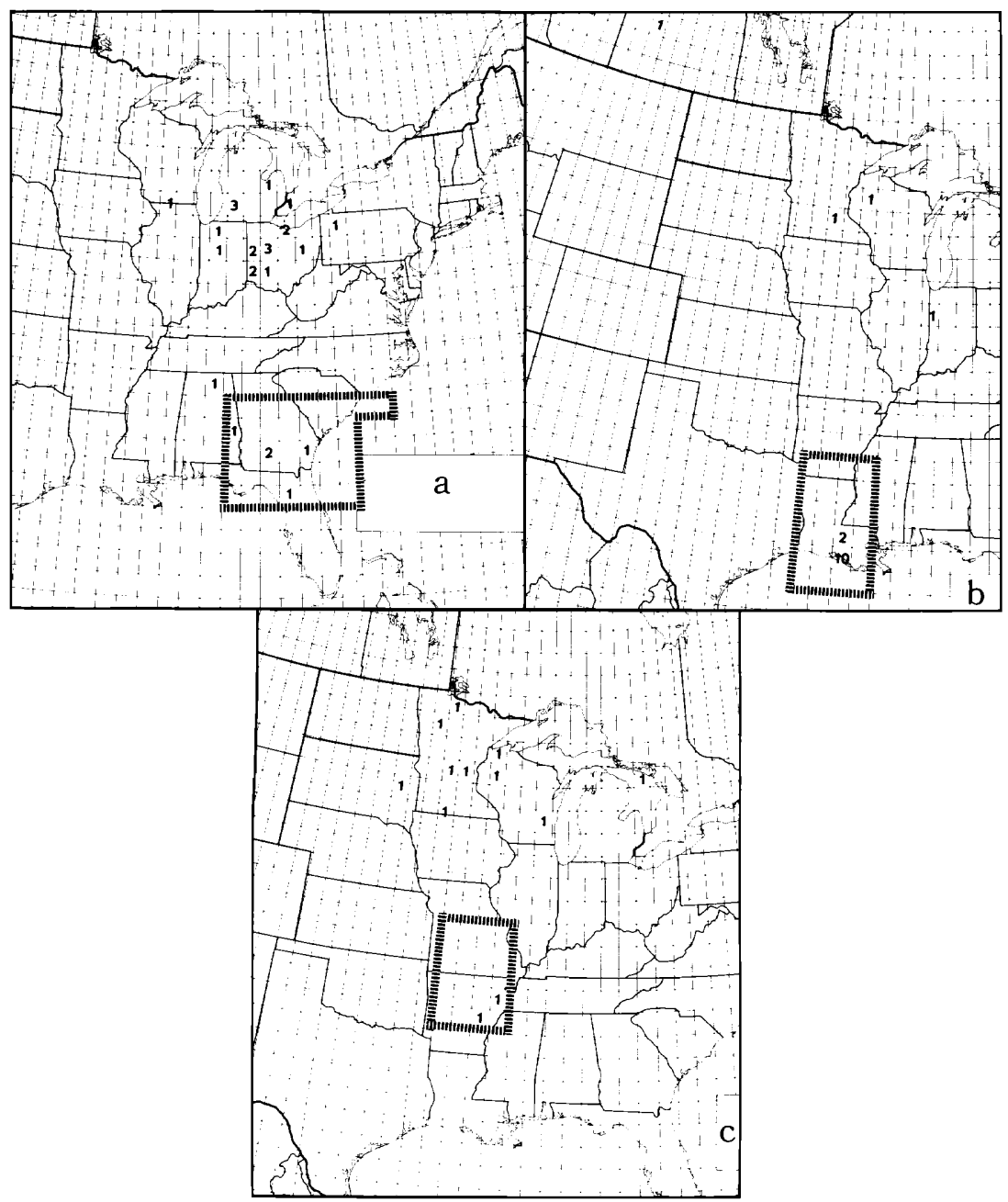

Figure 6. Number of recoveries by degree blocks during the reproductive-postreproductive period (25 April-15 October) for Red-winged Blackbirds banded during the winter-roost period (10 December-20 February) in regions 2 (Fig. 6a), 4 (Fig. 6b), and 10 (Fig. 6c).

few birds banded that have subsequently been recovered. The recovery effort, with the exception of region 7 , also has been very low in these same dominant winter-roosting regions, as well as in region 10 .

\section{DISCUSSION}

A precise picture of the continental patterns of movement and migration for the Red-winged Blackbird cannot be achieved at this time 
TABLE 6

Ranking of regions in North America as to banding and recovery effort for Red-winged Blackbirds during reproductive-postreproductive period, 25 April-15 October.

\begin{tabular}{|c|c|c|c|c|c|c|c|}
\hline \multirow[b]{2}{*}{ Region } & \multirow[b]{2}{*}{$\begin{array}{c}\text { Population } \\
\text { index }{ }^{1} \\
{[A]}\end{array}$} & \multicolumn{3}{|c|}{ Banding effort } & \multicolumn{3}{|c|}{ Recovery effort } \\
\hline & & $\begin{array}{c}\text { No. birds } \\
\text { banded in } \\
\text { region that } \\
\text { have been } \\
\text { recovered } \\
{[\mathrm{B}]}\end{array}$ & $\begin{array}{c}\text { Banding } \\
\text { effort } \\
\text { index } \\
{[\mathrm{B} / \mathrm{A}]}\end{array}$ & Rank & $\begin{array}{c}\text { No. } \\
\text { banded } \\
\text { birds re- } \\
\text { covered } \\
\text { in re- } \\
\text { gion } \\
{[\mathrm{C}]}\end{array}$ & $\begin{array}{c}\text { Recovery } \\
\text { effort } \\
\text { index } \\
{[\mathrm{C} / \mathrm{A}]}\end{array}$ & Rank \\
\hline 1 & 7.91 & 129 & 16.31 & 3 & 122 & 15.43 & 3 \\
\hline 2 & 8.18 & 80 & 9.77 & 6 & 81 & 9.90 & 6 \\
\hline 3 & 5.26 & 5 & 0.95 & 18 & 13 & 2.47 & 14 \\
\hline 4 & 17.43 & 198 & 11.36 & 5 & 200 & 11.47 & 5 \\
\hline 5 & 22.94 & 13 & 0.57 & 21 & 16 & 0.70 & 21 \\
\hline 6 & 6.07 & 0 & 0.00 & 27 & 3 & 0.49 & 22 \\
\hline 7 & 2.82 & 6 & 2.13 & 15 & 7 & 2.48 & 13 \\
\hline 8 & 14.28 & 10 & 0.70 & 19 & 40 & 2.80 & 12 \\
\hline 9 & 16.21 & 1 & 0.06 & 26 & 3 & 0.19 & 26 \\
\hline 10 & 18.63 & 42 & 2.25 & 13 & 23 & 1.23 & 20 \\
\hline 11 & 10.88 & 13 & 1.19 & 17 & 20 & 1.83 & 18 \\
\hline 12 & 22.51 & 114 & 5.06 & 9 & 95 & 4.22 & 9 \\
\hline 13 & 13.82 & 5 & 0.36 & 23 & 4 & 0.29 & 24 \\
\hline 14 & 49.97 & 34 & 0.68 & 20 & 26 & 1.92 & 17 \\
\hline 15 & 6.70 & 2,229 & 332.68 & 1 & 1,532 & 228.66 & 1 \\
\hline 16 & 23.00 & 190 & 8.26 & 7 & 122 & 5.30 & 7 \\
\hline 17 & 63.36 & 2,036 & 32.13 & 2 & 1,414 & 22.32 & 2 \\
\hline 18 & 48.21 & 18 & 0.37 & 22 & 0 & 0.18 & 27 \\
\hline 19 & 77.16 & 236 & 3.06 & 12 & 161 & 2.09 & 16 \\
\hline 20 & 14.06 & 24 & 1.71 & 16 & 32 & 2.28 & 15 \\
\hline 21 & 18.51 & 40 & 2.16 & 14 & 32 & 1.73 & 19 \\
\hline 22 & 28.73 & 385 & 13.40 & 4 & 370 & 12.88 & 4 \\
\hline 23 & 54.63 & 228 & 4.19 & 11 & 201 & 3.69 & 11 \\
\hline 24 & 44.17 & 299 & 6.77 & 8 & 202 & 4.57 & 8 \\
\hline 25 & 55.96 & 254 & 4.54 & 10 & 232 & 4.15 & 10 \\
\hline 26 & 90.56 & 16 & 0.18 & 25 & 31 & 0.34 & 23 \\
\hline 27 & 14.85 & 3 & 0.20 & 24 & 3 & 0.20 & 25 \\
\hline
\end{tabular}

${ }^{1}\left(\right.$ Land area $\left[\mathrm{km}^{2}\right] \times$ average number Red-wings per Breeding Bird Survey route $) / 10^{6}$. 


\section{TABLE 7}

Ranking of 13 regions in North America as to banding and recovery effort for Redwinged Blackbirds during winter-roost period, 10 December-20 February. Only regions containing at least 200,000 winter-roosting Red-wings are included in the analysis.

\begin{tabular}{|c|c|c|c|c|c|c|c|}
\hline \multirow[b]{2}{*}{ Region } & \multirow[b]{2}{*}{$\begin{array}{l}\text { Estimated } \\
\text { roosting } \\
\text { popula- } \\
\text { tion of } \\
\text { Red-wings }{ }^{1} \\
\left(\times 10^{6}\right) \\
{[\mathrm{A}]}\end{array}$} & \multicolumn{3}{|c|}{ Banding effort } & \multicolumn{3}{|c|}{ Recovery effort } \\
\hline & & $\begin{array}{c}\text { No. birds } \\
\text { banded in } \\
\text { region that } \\
\text { have been } \\
\text { recovered } \\
{[\mathrm{B}]}\end{array}$ & $\begin{array}{c}\text { Banding } \\
\text { effort } \\
\text { index } \\
{[B / A]}\end{array}$ & Rank & $\begin{array}{c}\text { No. } \\
\text { banded } \\
\text { birds re- } \\
\text { covered } \\
\text { in re- } \\
\text { gion } \\
\text { [C] }\end{array}$ & $\begin{array}{c}\text { Recovery } \\
\text { effort } \\
\text { index } \\
\text { [C/A] }\end{array}$ & Rank \\
\hline 2 & 3.87 & 117 & 30.23 & 1 & 195 & 50.39 & 1 \\
\hline 3 & 12.49 & 17 & 1.36 & 7 & 35 & 2.80 & 8 \\
\hline 4 & 41.93 & 129 & 3.07 & 5 & 159 & 3.79 & 7 \\
\hline 5 & 54.38 & 12 & 0.22 & 12 & 46 & 0.85 & 12 \\
\hline 6 & 1.15 & 8 & 6.98 & 4 & 8 & 6.96 & 6 \\
\hline 7 & 10.05 & 3 & 0.30 & 11 & 116 & 11.54 & 4 \\
\hline 8 & 1.37 & 1 & 0.73 & 9 & 15 & 10.96 & 5 \\
\hline 9 & 19.97 & 0 & 0.00 & 13 & 17 & 0.85 & 11 \\
\hline 10 & 20.95 & 29 & 1.38 & 6 & 13 & 0.62 & 13 \\
\hline 11 & 13.28 & 6 & 0.45 & 10 & 13 & 0.98 & 10 \\
\hline 12 & 5.25 & 93 & 17.71 & 3 & 98 & 18.67 & 2 \\
\hline 13 & 0.24 & 5 & 20.83 & 2 & 4 & 16.67 & 3 \\
\hline 14 & 4.32 & 5 & 1.16 & 8 & 12 & 2.78 & 9 \\
\hline
\end{tabular}

${ }^{1}$ Meanley, B. 1976. Unpubl. Prog. Rep., Work Units P-F-25.1, 25.2. Patuxent Wildl. Res. Center, Laurel, MD. 82 p.

because of the paucity of bandings and/or recoveries in many important regions of the species' range. Nonetheless, this study does provide considerable information that should prove useful in developing management strategies for Red-wing populations and the problems they create.

Red-winged Blackbirds are sometimes rather serious depredators of maturing grain crops (especially corn) in certain areas of North America during August and September (e.g., Meanley, 1971; Stone et al., 1972). The analyses on movements between the reproductive period and postreproductive period suggest that most of these depredation problems are caused by locally (within $200 \mathrm{~km}$ ) breeding or produced birds and not by far-ranging migrants. More intensive studies of late summerearly fall movement patterns of Red-wings in specific areas where crop depredations occur can be based on the data provided.

There apparently is considerable intermingling among breeding populations from widely divergent areas during the winter-roost period. 
Furthermore, although Red-wings appear to be rather sedentary during a single winter-roost period, they are not necessarily faithful to the same roosting area in subsequent winters. Intermingling does not occur, however, when winter-roost populations return to their breeding areas; virtually all birds return to the areas where they were hatched. The dispersal pattern in winter (e.g., birds from northern Ohio migrating to an area ranging from eastern North Carolina to western Alabama) could serve to reduce the impact on local breeding populations of any severe localized weather conditions in winter that result in large die-offs of roosting populations (Odum and Pitelka, 1939). The effects of a high mortality rate at a single roost or cluster of roosts in winter would be spread among Red-wing populations indigenous to a wide area.

Three important management implications are suggested from these findings: (1) reduction of populations of Red-wings that cause localized late-summer agricultural damage probably cannot be practically achieved through the mass killing of blackbirds in a few winter roosts in the southern United States (also see De Grazio et al., 1969; Dolbeer et al., 1976); (2) similarly, the large-scale reduction of Red-wing numbers at a few winter roosts probably will not result in any large-scale reduction of specific local breeding populations of Red-wings in North America the following summer; and (3) if a roosting population is removed from a local area during one winter, Red-wings from other areas will probably readily repopulate the area in subsequent winters if suitable roosting habitat and a source of food still exist.

An initial attempt has been made at tracking populations indigenous to the various regions as the birds move from their breeding areas to winter-roost areas and back again (Tables 4 and 5). The continued development of such a system is necessary if we are to understand the dynamics of Red-wing populations and, thus, be in a position to intelligently manage the continental population as bird-man conflicts become more complex in our increasingly crowded world (Dolbeer et al., 1976). Considerably more bandings and recoveries are needed, particularly in key regions (e.g., 3, 5, 7, 9, and 11) containing large populations of wintering birds. New techniques, such as telemetry or possibly the use of physiological markers, may also add substantial data on movement and migration patterns.

\section{SUMMARY}

The total recovery data (about 11,000 records) for banded Redwinged Blackbirds were analyzed to determine: (1) the general continental pattern of movements and migration, and (2) the banding and recovery effort for 27 regions of North America. In most regions except the northwest, Red-wings did not migrate long distances $(>200 \mathrm{~km})$ until after the fall molt was completed in October; thus, most crop-damage problems in late summer are caused by locally $(<200 \mathrm{~km})$-breeding or -produced birds. Apparently, intermingling of breeding populations from widely divergent areas (e.g., northcentral Ohio and Chesapeake 
Bay) occurs during the winter-roost period. Thus, the effects of a highmortality rate at a single roost or cluster of roosts in winter probably would be spread among Red-wing populations indigenous to a wide area. Intermingling of wintering populations does not occur, however, when these birds return to their breeding areas; virtually all birds return to within $50 \mathrm{~km}$ of where they were hatched. A preliminary information system was developed to keep track of the locations of populations indigenous to the various regions of North America as they go from their breeding areas to winter-roost areas and back again. This information system is incomplete at present because of the paucity of bandings and/ or recoveries in several important regions, particularly in the southern United States where large winter-roosting populations are found.

\section{ACKNOWLEDGMENTS}

I gratefully acknowledge the assistance of the Bird Banding Laboratory, Laurel, Maryland, for providing the recovery records. Appreciation is extended to C. R. Ingram, B. Meanley, P. P. Woronecki, J. L. Seubert, and J. S. Webb for their interest and help in various phases of the analysis.

\section{LITERATURE CITED}

Allen, A. A. 1914. The Red-winged Blackbird: A study in the ecology of a cat-tail marsh. Proc. Linn. Soc. New York, 24, 25: 43-128.

De Grazio, J. W., J. F. Besser, and J. L. Guarino. 1969. Winter distribution of blackbirds as related to corn damage control in Brown County, South Dakota. Trans. N. Am. Wildl. Nat. Resour. Conf., Wash., D.C. 2-5 March 1969, 34: 131-135.

DolbeER, R. A. 1976. Reproductive rate and temporal spacing of nesting of Red-winged Blackbirds in upland habitat. $A u k, 93: 343-355$.

Dolbeer, R. A., C. R. Ingram, ANd J. L. Seubert. 1976. Modeling as a management tool for assessing the impact of blackbird control measures. Proc. Vertebr. Pest Conf., 7: 3545. Univ. Calif., Davis.

Graham, F., JR. 1976. Blackbirds-a problem that won't fly away. Audubon, 78: 118-125.

LaUx, J. L. 1970. Non-breeding surplus and population structure of the Red-winged Blackbird (Agelaius phoeniceus). Ph.D. Dissertation, Univ. Mich., Ann Arbor.

Meanley, B. 1964. Origin, structure, molt, and dispersal of a late summer Red-winged Blackbird population. Bird-Banding, 35: 32-38.

- 1971. Blackbirds and the southern rice crop. U.S. Fish Wildl. Serv. Resour. Publ. 100. $64 \mathrm{p}$.

. 1975. The blackbird-Starling roost problem. Atlantic Nat., 30: 107-110.

Meanley, B., AND G. Bond. 1970. Molts and plumages of the Red-winged Blackbird with particular reference to fall migration. Bird-Banding, 41: 22-27.

Meanley, B. AND J. S. WebB. 1961. Distribution of winter Red-winged Blackbird populations on the Atlantic coast. Bird-Banding, 32: 94-97.

Nero, R. W. 1956. A behavior study of the Red-winged Blackbird. I. Mating and nesting activities. Wilson Bull., 68: 5-37.

Odum, E. P., and F. A. Pitelka. 1939. Storm mortality in a winter Starling roost. Auk, 56: $451-455$.

PaCKard, F. M. 1936. An analysis of some banding records of the eastern red-wing. BirdBanding, 7: 28-37.

Robbins, C. S., and W. T. Van Velzen. 1969. The breeding bird survey, 1967 and 1968. U.S. Bur. Sport Fish. Wildl. Spec. Sci. Rep., Wildl. 124. 107 p.

Royall, W. C., JR. 1973. The Common Grackle in Texas-a review of fifty years of band recovery data. Bull. Texas Ornithol. Soc., 6: 20-22. 
Smith, L. B., And R. D. Bird. 1969. Autumn flocking habits of the Red-winged Blackbird in southern Manitoba. Can. Field-Nat., 83: 40-47.

Stone, C. P., D. F. Mott, J. F. Besser, and J. W. De Grazio. 1972. Bird damage to corn in the United States in 1970. Wilson Bull., 84: 101-105.

U.S. Fish and Wildlife Service, Ohio Field Station, clo Plum Brook Station, Columbus and Taylor Rds., Sandusky, OH 44870. Received 30 March 1977, accepted 10 August 1977. 